\title{
The colors of the smells: the influence of culture and society in the visual design of packaging of perfume
}

abstract This paper presents a discussion about the socio-cultural influences on the use of the colors in the packagings in order to represent the smell of a perfume. We have observed that, in the market practice, certain colors are associated to certain categories of perfume. We know that color is an important element to be used in communication, being able to evoke feelings and memories in people. We argue that the appropriate use of colors will allow more effective communication of a perfume. Despite the perception being an individual phenomenon, literature has shown that there is a trend to a collective perception. A trend which is influenced by socio-cultural issues. Our hypothesis is that there is a relationship between market practices and consumer with regard the association established between colors and smells. That is the point which we will discuss in this paper. To do so, we make a brief introduction to the fragrance market and the role of packaging design. Then, we carry on presenting the colors of smells according to perfumery companies in their market practices. Forward, we analyze the potential of the colors to evoke certain fragrances, based on the results of an exploratory survey done with Brazilian consumers.

keywords design, culture, packaging, perfume, colors

\section{Introduction}

The Brazilian perfumery market has born in the early nineteenth century, when the Portuguese court arrived in Brazil (Silva, 2012, p.53). Initially, perfumes were exclusivity of the nobility. However, in the extent that the country was industrializing perfumes began to be produced on a large scale, being available to the masses. With the opening of trade abroad in 1990's, Brazil could import raw materials for perfumes and packagings. From then on the launching of perfumes has intensified. National perfumery market gains international features in that period (Silva, 2012, p.67). Today, two decades later, Brazil is one of the countries that drives the economy of toiletries, perfumes and cosmetics (ABIHPEC 2014, p.12). Growth in this segment gives room for growth in the packaging sector and thus an opportunity for professional development in the packaging design.

Packaging, because its technical function (protection and transportation) and because its function as means of communication, lacks studies that ranging from technical issues (shapes and raw materials) to symbolic issues (consumer's perception). In this paper we intend to discuss the symbolic issues which must be considered in a packaging design 
theme 3

identity

Figure 1,

The use of color so as to distinguish perfumes (2014), photos taken from Grupo Boticário website. strand 2

localities / globalities

for perfumes. In a project of this nature, where the thing which is sold is the fragrance with its promises of welfare, seduction, freshness (Ashcar, 2011, p.8), it is expected that a packaging communicates such attributes.

The use of graphic design so as to distinguish and assign identities to perfumes, becomes more frequent over the years. It has been influenced by the development of the graphic arts industry, which makes possible different forms of graphic expression in bottles and packagings. The color has been the most used element to create differentiation between perfumes. We can observe it by analyzing the perfumery market. The use of identical bottles, differing only by the colors and graphic elements, is a business strategy of some of the largest companies in the country, such as Natura ${ }^{2}$ and Phebo ${ }^{3}$. The perfumery company $O$ Boticário is also a good example regarding this strategy. The amphora shaped bottle has been used by the company since 1979 for different brands (Fig 1).

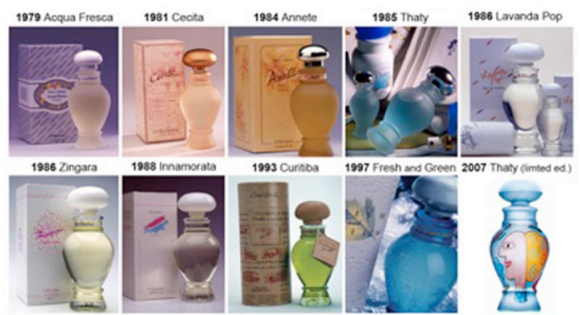

Taking into account that colors play an important role in the communication of a fragrance, our objective is to investigate how colors and smells can be associated. It is known that visually identify an odor is not a very easy task. Besides the smell evoke perceptions that vary from individual to individual, it is known that humans have difficulties to build images of smells and verbalize them (Wolfe et al 2012, p.416). Despite of the difficulty of associating the smell to the other senses, we can observe in the market the use of certain colors in order to identify certain smells.

\section{The colors of the smells: a market practice}

Before discuss the possible associations between colors and smells, it is important to highlight some of the features which can influence the perception of the smells. Perfume is a product which can vary from a simple to a complex composition (in average 80 ingredients). It is a mixture of odors extracted from vegetables (flowers, fruits, wood, etc.), from animal secretions (deer musk, civette, castoreum, amber gris) and/or those produced in laboratories (synthetic materials). The possibility of mixtures is uncountable. Perfumes may also vary in concentration and intensities. From the most to the least concentration of extract we have: parfum, eau de parfum, eau de toilette, eau de cologne and deo cologne (Silva, 2012, p.26-30).

In the popular perfumery is common to find perfumes with lower concentration of raw material (deo colognes). It is also common to find perfumes whose identity is defined by

\footnotetext{
${ }_{2}^{2}$ Natura Humor. In: Natura <http://www.natura.com.br/nossasmarcas/humor> 12/20/2013.

${ }^{3}$ Phebo fine fragrances. In: Phebo <<https://www.phebo.com.br/Loja/Categoria/112?linha=124>> 12/20/2013.
} 
main ingredient, such as Lavender. These popular fragrances are sold in supermarkets and in drugstores for a lower price. Insofar as a perfume becomes more sophisticated the trend is that they have generic names, disassociated with the ingredient and associated with a certain quality. These finest fragrances are usually sell in perfumery specific stores. Some can be associated with the reputation of a brand, as Channel $n^{\circ} 5$ for instance. Others have names expressing a feeling as Euphoria by Calvin Klein. Apparently, the more elaborate is the formula and the more generic is the message, it becomes more complex to visually represent the smells.

Taking the lavender smell as an example, when the perfume is named as Lavender ${ }^{4}$ it is common to find the use of green and purple colors so as to represent the smells. Making reference to the color of lavender field. When lavender is used combined with other ingredients, and moreover, when it is associated a generic name, the use of colors does not follows a pattern. It seems to depend on the intentions under the brand. Bellow we present a comparison between the packagings of popular fragrances with those sold by $O$ Boticário and Avon Company.

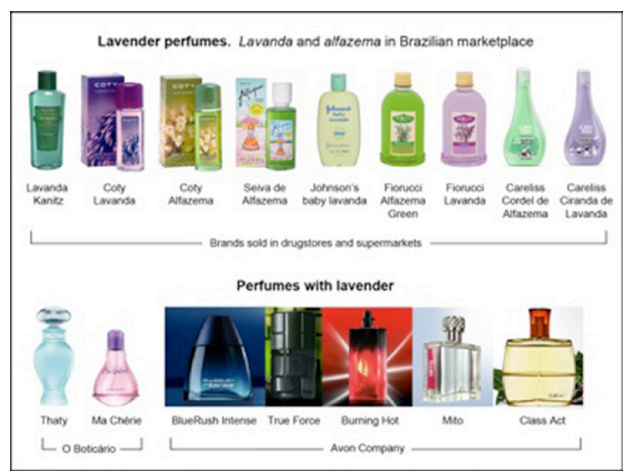

Figure 2. Lavender perfumes (2014), figure prepared by the authors based on the research.

Because of the difficulty in verbalizing the feelings elicited by a smell, we tend to associate it with what is familiar to us. After all, the process of meaning is related to experience. Therefore, it is common to find associations between colors and smells based on the colors of the raw materials used in the perfumes. This assumption is confirmed when we analyzed the colors used by some fragrance companies so as to represent the smells.

Given the extensive range of ingredients available in the world of perfumery it is a common market practice to classify fragrances in olfactory families. The main olfactory groups are: citrus, floral, aromatic, woody, oriental and chypre (Osmoz, 2014). Although this classification varies from company to company. In this paper we analyze the four olfactory families most used in the Brazilian perfumery market: citrus, floral, woody and oriental. From this selection we investigated in the catalogs and websites of different companies (fragrances suppliers) what were the colors used to represent such olfactory families (Fig. 2). 
theme 3

identity

Figure 3.

Colors used to represent some of the olfactory families (2013), figure prepared by the authors based on the research. strand 2

localities / globalities

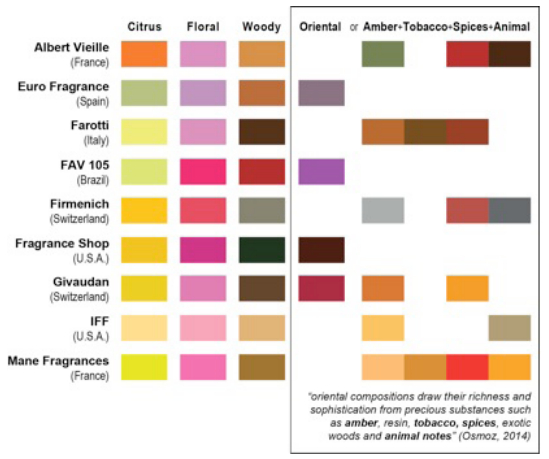

2. Consumers perception: the meaning of the colors

Despite of the experience with a color being something unique and personal, experiments (Goethe, 1970; Itten, 1970) have proved that we can have a collective interpretation for it. It is worth note that our perception is related to what we see and to what we experience. According to Peirce, "the interpretation itself is experience. ("CP 7.527 " as cited in IBRI, 1992, p.4). Therefore, we argue that the market practices (i.e., the colors that are commonly used in the packaging) can influence in the relationship consumers established between colors and smells.

Although those studies have shown a consensus regarding the psychological effect of color, it is known that the meanings assigned to the colors vary from culture to culture (Heller, 2013). Therefore, we decided to conduct an online survey with consumers in order to check whether there is a collective perception when respondents associate colors to smells. In addition to this, we also intended to check whether the Brazilian respondents would inform the same colors used by the global companies (as shown in Fig. 3).

The online survey consists in an initial investigation. It was elaborated in Google Drive tool and it was distributed through the social network of the authors, composed mostly of designers and design students. However, the professional occupation was not an issue of selection. Respondents were encouraged to spread the survey to their respective social networks. Only personal information as age, gender and city of residence were collected. In a period of one month (from 11/17/2013 to 12/13/2013), we obtained a total of 159 respondents (106 women and 53 men). The majority of respondents (80\%) were under 35 and over $90 \%$ were from the Southeast region residents.

Respondents were not asked about their habits of consumption of perfumes. They were only asked to freely associate four olfactory families (citrus, floral, woody and oriental) to one or more colors. We opted to qualitative approach using open-end questions. With that, we collected different ways of expressing colors 5 . For the tabulation of the results we considered the variations of tones of a given color as the same color. That is, when we mention green, we refer to the different kinds of green (dark, light, ect.) informed 
by the respondents. For the citrus family from the total of 208 mentioned colors the most mentioned were: green (42\%), yellow (24\%) and orange (23\%). For the floral family, from 226 mentions, the most mentioned colors were: pink (45.6\%), purple/lilac (15.5\%) and yellow (11.5\%). In what concerns to woody family, 190 colors were mentioned and the three most mentioned were: brown (51,6\%), yellow (8.6\%) and green (6.8\%). Finally, for the oriental family 198 colors were mentioned, the three most mentioned were: red (31.8\%), yellow (10.6\%) and white (9\%).

From the results we can make some analyzes. The colors indicated by each of the respondents have close relationship with the ingredients that make up each of the families of fragrances. This association is stronger in the olfactory families with which we can establish a concrete relationship, such as floral (flowers), woody (wood) and citrus (citrus fruits). The colors mentioned by respondents also have close relationship with market practices (Fig. 3), which leads us to infer that the experiences of daily life may have influence on consumers perception.

In the citrus family, over $60 \%$ of the listed colors were green and yellow, which are the colors of the two popular citric fruits in Brazil (lemon and orange). Regarding to the floral family, pink and lilac/purple totaled more than $60 \%$ of the mentioned colors. It is probably due to the colors that are commonly found in flowers. Taking a look at the website of Natura and O Boticário, for instance, we can find perfumes that have this color. With regard to the woody family, the color brown is the most mentioned by the half of respondents. It is followed by yellow and green, colors that we can also find in related to the woods (leaves and twigs).

Finally, it was with regard to the oriental family in which we could observe the most variation of the results. There was a predominance of warm colors that has everything to do with the approach of this olfactory family, which propose to evoke the sensation of warm and sensuality (Osmoz, 2014). However, to the oriental family were also informed blue and white as representative colors, in opposition to the warm idea. We could infer that this association has more to do with the reference these respondents have from Orient, than with the fragrance attributes. Colors like blue and white are quite common in Asian paintings of landscapes (specially in Japanese Culture). The understanding of the perception of such abstract issues as oriental family deserves a deep research.

\section{Conclusion}

The analyzes presented in this paper lead us to conclude that the culture and society influence the way consumers perceive colors. We assume that it is a subject that requires deepening research. We believe that as best as designers could understand the perception of consumers, they can design packagings more efficiently. We point as possibilities for future studies the documentation and analysis of packaging separated in groups of olfactory families. In face of the results concerning to the oriental family, we recommend to investigate what consumers truly understand by such families fragrance. In addition to this, we recommend other color perception surveys in which consumers being subjected to smells tests.

\section{References}

Ashcar, R. (2011). Guia de perfumes. São Paulo: Officiel. Conheça as famílias olfativas. In: FAV105 <http://www.fav105.com.br/familia.html> $12 / 18 / 2013$ Demonstration Formulas. In: IFF Fragrance Ingredients <http://fragranceingredients.iff. 
com/formulas/formulas.aspx\#> 12/18/2013

Fragrance \& Flavour Ingredients Catalogue 2012. In: Mane <http://www.mane.com/sites/ default/files/file-block/fragrance_flavour_ingredients_catalogue-2012.pdf> 12/18/2013 Fragrance Families. In: Fragranceshop <http://thefragranceshop.com/shop-by-fragrancestyle/> 12/18/2013

Fragrance Ingredients Index. In: Givaudan < http://www.givaudan.com/eindex/> $12 / 18 / 2013$

Goethe, J. W. (1970). Theory of colours. Cambridge, Mass: M.IT. Press.

Heller, E. (2013). A psicologia das cores: como as cores afetam a emoção e a razão. São Paulo: G. Gili.

Ibri, I. A. (1992). Kósmos Noetós: a arquitetura metafísica de Charles S. Peirce. São Paulo: Perspectiva: Hólon.

Itten, J. (1970). The elements of color. New York: Van Nostrand Reinhold Company. Lavender perfumes (photos used in figure 2). In: Ciclo Vita < http://www.ciclovita.com.br> 03/21/2014; Lojas rede <http://busca.lojasrede.com.br/busca/lavanda.aspx?q=lavanda> 03/21/2014; Submarino <http://www.submarino.com.br/marca/coty> 03/21/2014 The perfume character. In: Euro Fragrance <http://www.eurofragance.com/caracter_ perfume.php>03/21/2014

Nossa história. In: Grupo Boticário < http://nossahistoria.grupoboticario.com.br/> $03 / 18 / 2014$

Notes and Olfactory Families. In: Farotti Essenze <http://www.farotti.it/en/desc_olfattive. asp $>12 / 18 / 2013$

Olfactory Family. In: Osmoz <http://www.osmoz.com/ encyclopedia/olfactory-groups> $03 / 18 / 2014$

Olfactory note. In: Albert Vieille <http://www.albertvieille.com/en/read/our-rawmaterials-23/olfactory-notes-25.html>12/18/2013

Panorama do setor. In: ABIHPEC. Associação Brasileira da Indústria de Higiene Pessoal, Perfumaria e Cosméticos <http://www.abihpec.org.br/wp-content/uploads/2014/o1/ Panorama-do-setor-PORT-10jan2014.pdf> 12/03/2014

Perfumery Ingredients. In: Firmenich <http://www.firmenich.com/e-catalog/index.Ibl> $12 / 18 / 2013$

Perfumes with lavender. In: Perfumaria Avon <http://www.perfumariaavon.com.br/ perfumes/fragrancias.php> 03/21/2014; O Boticário <http://www.boticario.com.br/ perfumaria/Lavanda ?map=c,spec_fct_119>03/21/2014

Silva, Camila Assis Peres. Perfume, história e design: o papel das embalagens no mercado brasileiro de perfumaria. 2012. 198f. Dissertação (Mestrado em Design) - Universidade do Estado do Rio de Janeiro, Escola Superior de Desenho Industrial, Rio de Janeiro. 2012. Wolfe, J. M., Kluender, K. R., Levi, D. M., Bartoshuk, L. M., Herz, R. S., Klatzky, R. L., et al. (2012). Sensation \& Perception (3rd Edition). Sunderland, MA: Sinauer Associates. 